\title{
Technology, Policy Distortions and the Rise of Large Farms
}

\author{
Wenbiao Cai \\ Department of Economics Working Paper Number: 2015-03
}

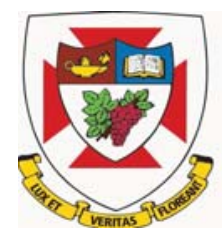

THE UNIVERSITY OF WINNIPEG

\author{
Department of Economics \\ 515 Portage Avenue \\ Winnipeg, Canada R3B 2E9
}

This working paper is available for download at:

http://ideas.repec.org/s/win/winwop.html 


\title{
Technology, Policy Distortions and the Rise of Large Farms
}

\author{
Wenbiao Cai
}

August 10, 2015

\begin{abstract}
Between 1900 and 2002, mean farm size in the U.S. quadrupled. The increasing dominance of large farms has raised concerns about inequality and questions about the role of policies in fueling this trend. I construct a two-sector model with an endogenous size distribution of farms, and use the model to show that factor endowment and technological change cannot fully account for long-term changes in farm size. Utilizing a novel set of farm-level statistics constructed from historical census of agriculture, I further show that policy distortions to farm size are regressive and are crucial for the rise of large farms.
\end{abstract}

JEL Codes: O11; O13; Q18

keywords: U.S. Farm Size; Technology; Policy Distortions

Department of Economics, University of Winnipeg. Email: we.cai@uwinnipeg.ca. I would like to thank B. Ravikumar and Guillaume Vandenboucke for conversations when I started this project at Iowa, and Manish Pandey for many helpful suggestions. This paper has benefited from comments by Ashantha Ranasinghe, Chad Lawley, Brian Oleson, John Dalton, and seminar participants at University of Manitoba, Wake Forest University and Jinan University. Yiyi Gong provided excellent research assistance. All errors are my own. 


\section{Introduction}

Between 1900 and 2002, average land size of U.S. farms quadrupled. Productive resources and output are increasingly concentrated in farms from the upper tail of the size distribution. The increasing dominance of large farms has raised concerns about inequality, and questions about the role of farm policies in fueling this trend. This paper is a quantitative inquiry into the sources of long-term changes in farm size in the U.S.

Many factors could have contributed to the expanding farm size and I focus on a subset of them: the accumulation of capital and land, technological progress, and policy distortions. The main contribution of this paper is to quantitatively evaluate with an equilibrium model the importance of these factors in explaining long-term changes in farm sizes. In doing so, I also utilize a novel data set constructed from census of agriculture between 1900 and 2002. This data provides harmonized farm-level statistics on key aspects of farm size, in particular the distributions of capital, labor, land, and output across farms of different land sizes. These statistics are useful for identifying misallocation of productive resources across farms due to policy distortions.

I begin by documenting key facts about U.S. farm size over the period 1900-2002. The share of labor in agriculture declined continually, and mean farm size grew over time as land was consolidated among farmers that remained. Increasing farm size was observed across different geographical regions and different types of production. Family farms remained the dominant form of organization, but the composition of farms changed dramatically, and the "rise of large farms" was a distinct feature. At the beginning of the 20th century, one in three farms in the U.S. operated with a plot of land below 20 hectares. The same was true in 2002. This contrasts with the rapid increase in the share of farms above 200 hectares, from 3 percent to 16 percent. By the end of the century these large farms accounted for 80 percent of all farm land, 52 percent of all capital in farms, and 58 percent of all farm output. A simple calculation indicates that the Gini coefficient for land increased from 0.56 in 1900 to 0.78 in 2002 , and for capital from 0.38 to 0.47 .

To guide the analysis, I adopt the model of farm size in Adamopoulos and Restuccia (2014b). In the model individuals have different managerial skills in agriculture and they 
can either spend their time operating a farm or working for a wage in non-agriculture. A farm consists of one operator with a span of control over land and capital as in Lucas (1978), and the operator's skills determine the optimal farm size. I assume that managerial skills are distributed according to a log-normal distribution, and calibrate the model to match aggregate observations and the distribution of farms by land size observed in 1900. The calibrated model also matches a rich set of non-targeted farm-level statistics in 1900, such as the distribution of land and capital by farm size, and the disparities in value added per worker and capital-land ratio across size categories.

In the model, exogenous growth in aggregate stock of capital, land and total factor productivity (TFP), in conjunction with a subsistence constraint in preferences, leads to reallocation of labor from agriculture to non-agriculture, which in turns generates growing farm size as land is in the hands of fewer farm operators. A natural starting point is to assess whether observed changes in these aggregate factors can explain observed changes in farm size. For this purpose, from the data I measure the growth rate of TFP, aggregate stock of capital per worker and land per worker. With these exogenous processes the model generates aggregate allocations that are quantitatively consistent with data - it accounts for 90 percent of the decline in the share of labor in agriculture, 80 percent of the growth in agricultural value added per worker, and all of the decline in the relative price of agricultural output. These aggregate factors, however, fare less well explaining changes in the composition of farms. On the one hand, the model generates a counterfactual decline in the share of small farms, the constancy of which is a salient feature of the data. On the other hand, the reallocation of resources from small to large farms is markedly slower in the model relative to data. In other words, the accumulation of capital and land together with technological progresses cannot fully account for the "rise of large farms."

Next I focus on policies that distort allocations across farms as another source of changes in farm size. Government subsidies have been an integral part of U.S. agriculture since the Agricultural Adjustment Act (1933). U.S. farm policies are complex, both in terms of scope and implementation, and have evolved substantially over time. For a review of U.S. farm policies, see Gardner (1992) and Sumner et al. (2010). The key hypothesis here is that these 
policies tend to favor large farms more than small ones, either directly and indirectly. I argue that core components of U.S. farm policies have a built-in size-dependent structure. Most farm subsidies go to so-called "program crops" such as cotton, wheat, soybeans and upland cotton. Farms producing these crops naturally tend to have a larger land size, compared to farms producing non-program crops. Census data also reveals that the probability of enrolling in government programs significantly increases with farm size, and large farms account for most of the government payments. In contrast, certain clauses in the farm bills are adversary to small farms, e.g., the 2008 farm bill stipulated that farms below 10 acres were precluded from receiving a direct, counter-cyclical payment. ${ }^{1}$ Sumner (2014) also notes that "truly tiny farms do not even bother filing for subsidies". In fact, Key and Roberts (2007) claim that most of the increase in mean farm size in the U.S. is driven by farm policies.

I follow Restuccia and Rogerson (2008) and model distortions to optimal farm size as ad valorem taxes on farm output, with negative taxes interpreted as subsidies. Importantly, these taxes are allowed to correlate with managerial skills and in equilibrium with farm size. I assume a nonparametric distribution of taxes, and use the model and the observed size distribution of farms to pin down the distribution. The basic idea is to choose a distribution of taxes over managerial skills such that given the exogenous processes as before, the model exactly matches the size distribution of farms in the data for each year. Then I evaluate the effect of taxes on farm-level allocations, namely the distribution of capital, land, and output across farms of different sizes, and on employment and productivity in agriculture. I find that distortions to farm size significantly alter the allocation of resources across farms, in a way that is consistent with data. As in the data, the share of capital and output accounted for by small farms in the distorted economy displays little variation over time. Moreover, there is rapid reallocation of capital, land, and output towards large farms - by 2002, farms above 200 hectares account for 76 percent of total land in farms, 52 percent of total capital in farms, and 58 percent of total agricultural output in the model. These numbers are nearly identical to actual ones. Despite their large distributional effects, these distortions have a very small impact on employment and value added per worker in agriculture.

\footnotetext{
${ }^{1}$ Exceptions are made if the farm is owned by a socially disadvantaged or limited resources farmer or rancher.
} 
Inspecting the estimated distribution of taxes reveals several interesting observations. To reproduce observed changes in the size distribution of farms, the farm-size distortions are necessarily regressive, that is, the rate of subsidy increases with farm size. To the extent that these distortions are symptoms of farm policies, such policies in the U.S. are "prolarge." This form of regressive distortions in the case of the U.S. contrasts with that found in Adamopoulos and Restuccia (2014b) for poor countries. The authors argue that many institutions and policies in poor countries are "pro-small" and reduce productivity of large farms disproportionately. In the case of U.S., however, I find that farm-size distortions are immaterial for aggregate productivity. The reasons are (i) the magnitude of farm-size distortions are small - average subsidy is merely 6 percent of agricultural value added; (ii) both the magnitude and regressiveness of farm-size distortions have diminished over time.

This paper adds to previous research that examines long-term changes in farm size and productivity in U.S. agriculture. For an excellent summary of historical development of U.S. farming over the 20th century, see Gardner (2006) and reference therein. Much of the facts about increasing mean farm size have been documented in Dimitri et al. (2005). The exceptional growth of productivity in U.S. agriculture has also inspired numerous research into its sources, examples include Griliches (1963), Khaldi (1975), Jorgenson and Gollop (1992) and Huffman and Evenson (2001). While different hypothesis have been proposed to explain the changes in farm size and productivity, most of these studies are either qualitative in nature or consider the dynamics of farm size and productivity in separation. This paper analyzes these two aspects of agriculture jointly in an equilibrium framework.

Kislev and Peterson (1982) is perhaps the first paper to use an equilibrium model to understand growing mean farm size in the U.S. They highlight the role of falling price of capital, relative to wage in non-agriculture, in driving farm consolidation and consequently increasing average acreage. In addition to this mechanism, the current paper also emphasizes that farm-size distortions are crucial for the changes in the size distribution of farms. Manuelli and Seshadri (2005) develops a neoclassical growth model with an endogenous farm size distribution to understand historical diffusion of tractors in U.S. agriculture. The focus of that paper, however, is to understand reasons behind seemingly slow diffusion of tractors, 
and not those of changes in farm size distribution.

This paper also relates to the literature on misallocation across production units, led by Restuccia and Rogerson (2008) and Hsieh and Klenow (2009). For a recent review of the literature, see Restuccia and Rogerson (2013). With few exceptions, existing research have focused mainly on the manufacturing sector, e.g., Guner et al. (2008), Cai and Pandey (2013), Garicano et al. (2013), Midrigan and Xu (2014), Garcia-Santana and Pijoan-Mas (2014), and Bento and Restuccia (2015). The consensus from these papers is that plant-level distortions could lead to sizeable losses in aggregate productivity. This paper instead finds that while distortions to farm size are crucial for long-term changes in farm size distribution in the U.S., they are less relevant for aggregate productivity.

My paper is closely related to Adamopoulos and Restuccia (2014b), who investigate quantitatively misallocation in agriculture of poor countries and the implication for crosscountry productivity differences. The key difference is that I study long-term changes in farm size and agricultural productivity in the U.S, while they focus on cross-country differences at a point in time. This paper complements theirs in two important ways. First, Adamopoulos and Restuccia (2014b) treat the U.S. as a frictionless benchmark. Their model, when placed in the historical context of the U.S., reveals that distortions to farm size are also systematic in the U.S. and more importantly, regressive. Treating U.S. agriculture as frictionless possibly places a bigger burden on distortions in poor countries in order to reconcile observed cross-country disparity in farm size. Second, this paper constructs a novel set of data on the distribution of capital, land, and output by farm size. These statistics provide additional disciplines on the empirical relevance of farm-size distortions in the U.S. Since such detailed statistics are generally unavailable outside the U.S., especially in poorer countries, Adamopoulos and Restuccia (2014b) instead rely on specific institutional reforms or policies changes to evaluate the importance of farm-size distortions in poor countries. ${ }^{2}$

The rest the paper is organized as follows. Section 2 presents the facts, Section 3 the model and Section 4 the quantitative results. Section 5 concludes.

\footnotetext{
${ }^{2}$ Two other papers that use farm-level data to study misallocation across farms are Restuccia and Santaeulalia-Llopis (2014) and Adamopoulos and Restuccia (2014a). Both of them focus on developing countries.
} 


\section{Facts on U.S. Farm Size}

The main source of data is census of agriculture between 1860 and 2002, available from the U.S. Department of Agriculture. ${ }^{3}$ The census of agriculture started in 1840, and was conducted centennially until 1920. After that the census was conducted every five years between 1900 and 1950, in 1954, every five years between 1954 and 1974, in 1978, 1982, and then again every five years between 1982 and 2002.

The unit of observation in the census is a farm, which is defined as an operation that produced or normally would have produced a given amount of output, regardless of ownership. From each census, I extract summary statistics by land size of a farm. These statistics include market value of output produced, value of capital stock, quantity of land, value of land and buildings, number and hours of farm operators, hired labor and their hours, and government payments. These statistics are not available in every census; and in some cases, the definition of a variable changed across censuses even though the same variable is tabulated. Further detail on variable definition and procedures to make them consistent over time are delegated to a separate online appendix.

\section{Observation 1: Over time U.S. agriculture has fewer labor, higher productiv-} ity, larger and more specialized farms. In 1900, agriculture employed 40 percent of the labor force and produced 22 percent of gross domestic product (GDP). By 2002, these shares had dropped to less than 2 percent. The number of farms reduced from 6 million in 1900 to less than 2 million in 2002. These are well-know features of the process of structural transformation. Labor productivity grew enormously to compensate for the decline of labor in agriculture. Between 1900 and 2000, real value added per worker in agriculture grew at an annual rate of 3 percent. This amounts to doubling every 25 years. At the same time, total factor productivity (TFP) for agriculture grew at an annual rate of 1.4 percent. The productivity growth in agriculture dwarfed that in non-agriculture and that in the aggregate. Over the same period, annual growth rate for real GDP per worker was 1.6 percent while that for aggregate TFP was 0.6 percent.

\footnotetext{
${ }^{3}$ The link to census is http://www.agcensus.usda.gov/Publications/Historical_Publications/
} 
Family farms remain the dominant form of organization. In 2002, 93 percent of all farms are "family or individual farms." ${ }^{4}$ Nevertheless, the production structure has changed significantly. Most notably, farms were getting larger. Average land size of a farm nearly tripled from 60 hectares to 168 hectares. Meanwhile, farms were increasingly specialized. The average number of commodities produced per farm reduced from 6 in 1900 to roughly 1 in 2002 (Dimitri et al., 2005).

The expansion of farm size was observed across different geographical regions and commodities. Geographically, the fastest increase was observed in the west, where mean farm size increased 4 fold between 1900 and 1970. In the north central regions and in the south, the increase was roughly 2 -fold. The least increase was observed in the north eastern region, where average acreage increased by 50 percent. Another notable feature is that in each of these regions, the growth in mean farm size appeared to commence only after 1930. See Figure 1.

Unfortunately, data on average farm size by commodity that goes back to 1900 is not available. But more recent census data shows that the increase in average farm size is not unique to specific commodities. Between 1987 and 2007, average acreage tripled for farms producing corns, and doubled for farms producing cotton, rice, soybeans, and wheat. Measured by number of herds per farm, the average size of farms producing broilers and cattle also more than doubled, while that of hog farms increased by a factor 20 (MacDonald, 2011, Table 2). Similar observations are also documented in Key and Roberts (2007).

\section{Observation 2: Small farms stagnate while resources shift from mid-size farms}

to large ones The changes in average farm size masked more dramatic changes in allocation of resources across farms. To fix notation, I define small farms as those with a plot of land less than 20 hectares, mid-size farms as those with land between 20 and 70 hectares, and large farms as those with land above 200 hectares. On the one hand, the share of large farms increased from 3 percent in 1900 to 16 percent in 2002. On the other hand, large farms replaced mid-size farms instead of small ones. Over the same period, the share of midsize farms decreased by half from 48 percent to 24 percent, whereas the share of small farms

\footnotetext{
${ }^{4}$ Partnership is more common among larger farms. For example, 23 percent of farms above 200 hectares are organized as partnership, compared to less than 5 percent for farms below 20 hectares.
} 
stayed virtually the same over one hundred years.

Relative to the changes in the farm size distribution, the changes in the distribution of capital, land, and output across farms were even more dramatic. In 1900, large farms accounted for 37 percent of all land in farms and 11 percent of all capital in farms. By 2002, these shares had increased to 80 percent and 50 percent, respectively. Inspecting the distribution of output across farms reveals the same trend. The share of total output accounted for by large farms increased from 20 percent in 1940 to 58 percent in 2002 .

Again, resources shifted from mid-size farms toward large farms. The share of capital and land accounted for by mid-size farms decreased from 39 percent and 44 percent in 1900 to 5 percent and 18 percent in 2002, respectively; and the share of output decreased from 33 percent to 13 percent between 1945 and 2002. In contrast, the share of capital, land, and output accounted for by small farms changed minimally over the same period.

\section{Observation 3: Large farms are more productive, more likely to enroll in} government programs and account for most of the government payments. I construct two measures of productivity by farm size from the 2002 census. The first measure is value added per worker. In calculating the number of workers for a farm, both farm operators and hired workers are included, weighted by their respective hours of work. By this measure, the dispersion in labor productivity across farms is large. For example, farms above 200 hectares were 9 times more productive than farms below 20 hectares. The higher labor productivity for large farms is only partially accounted for by more capital and land per worker. To see this, I calculate total factor productivity by farm size. ${ }^{5}$ TFP, like value added per worker, also increases with farm size: TFP for farms above 200 hectares was four times that for farms below 20 hectares. See Figure 2.

Larger farms are also more likely to enroll in various government programs. Census reports for each size category the number of farms enrolled in each of the following programs: direct payment, land conservation and crop insurance. In 2002, less than 15 percent of farms below 20 hectares were enrolled in each of these programs. In contrast, 67 percent of farms

\footnotetext{
${ }^{5}$ TFP for farms in size class $j$ is calculated as $A_{j}=y_{j} /\left(k_{j}^{\alpha} \ell_{j}^{\theta} h_{j}^{1-\alpha-\theta}\right)$, where $y, k, \ell, h$ is value added, capital, land, and labor, respectively. Factors shares $\alpha, \theta$ are from Valentinyi and Herrendorf (2008).
} 
above 200 hectares were enrolled to receive direct payments, 22 percent in land conservation, and 55 percent in crop insurance. Large farms also accounted for most of the government subsidies from these programs. In 2002, farms above 200 hectares accounted for 72 percent of direct payments, 61 percent of payments for land conservation, and 87 percent of payments for crop insurance.

\section{Model}

The economy has an agriculture sector and a non-agriculture sector. Each sector produces a single consumption good. There is a stand-in household that consists of a continuum of mass one members. Members have different managerial skills, denoted by $s$. These skills are random draws from a cumulative density function $F(s)$ with finite support $S=[\underline{s}, \bar{s}]$.

Preferences Household preferences are defined over two consumption goods as follows:

$$
\eta \log \left(c_{a}-\bar{a}\right)+(1-\eta) \log \left(c_{n}\right)
$$

where $c_{a}$ and $c_{n}$ is consumption good produced in agriculture and non-agriculture, and $\eta$ and $(1-\eta)$ their respective weight. The parameter $\bar{a}>0$ denotes the minimum consumption of goods produced in agriculture. Therefore, preferences are non-homothetic.

Technology Output in non-agriculture is produced by a representative firm using the following technology:

$$
Y_{n}=A K_{n}^{\alpha} N_{n}^{1-\alpha}
$$

where $Y_{n}$ is output, $A$ is total factor productivity (TFP), $K_{n}$ is capital, $N_{n}$ is labor, and $\alpha$ is the capital share.

The production unit in agriculture is a farm, which consists of a farm operator with managerial skill $(s)$, and capital $(k)$ and land $(\ell)$ employed in production. Output from such 
a farm is given by:

$$
y_{a}(s)=A \kappa\left[\theta k^{\rho}+(1-\theta)(s \ell)^{\rho}\right]^{\frac{\gamma}{\rho}}
$$

The parameter $\kappa$ represents the agriculture-specific efficiency. The parameter $\theta$ captures the relative importance of land and capital in production. The parameter $\gamma \in(0,1)$ governs the span of control as in Lucas (1978). Finally, the parameter $\rho$ controls the elasticity of substitution between capital and land.

The economy is endowed with capital stock $K$ and land $L$. The stand-in household owns all factors of production. There are competitive rental markets for labor, capital, and land. There are also competitive goods markets.

Optimization The stand-in household allocates members between working in agriculture and non-agriculture. Those who work in agriculture are farm operators. I adopt the timing in Adamopoulos and Restuccia (2014b) such that managerial skills of farm operators are realized only after they are assigned to the agricultural sector. Therefore, I abstract from the selection of farm operators based on their skills.

Farm operator with managerial skill $s$ solves the following problem:

$$
\begin{array}{ll}
\max _{\{k, \ell\}} & p_{a} A \kappa\left[\theta k^{\rho}+(1-\theta)(s \ell)^{\rho}\right]^{\frac{\gamma}{\rho}}-r k-q \ell \\
\text { s.t. }: & k \geq 0, \ell \geq 0,
\end{array}
$$

where $p_{a}$ is the price of agricultural output, $r$ is the rental price of capital, and $q$ is the rental price of land. All prices are expressed in terms of non-agricultural output. Let $k(s)$ and $\ell(s)$ denote the optimal demand function for capital and land, and $\pi(s)$ the associated maximized profit that accrues to the farm operator. Given the distribution of managerial skills, the model generates endogenously a distribution of optimal land size $\ell(s)$, and correspondingly, a distribution of capital $k(s)$, land $\ell(s)$ and output $y_{a}(s)$.

Members working in non-agriculture supply labor to the representative firm and earn market wage $w$. Let $N_{a}$ denote the measure of farm operators, then the measure of workers 
in non-agriculture is $1-N_{a}$. Income for the household consists of wage income, rental income from capital and land, and profits from farms. Denote household income by $I$, then $I=w\left(1-N_{a}\right)+N_{a} \int_{S} \pi(s) d F(s)+r K+q L$. The household's problem is to choose the allocation of labor $\left(N_{a}\right)$ and consumption goods $\left(c_{a}, c_{n}\right)$ to maximize utility, i.e.,

$$
\begin{aligned}
\max _{\left\{N_{a}, c_{a}, c_{n}\right\}} & \eta \log \left(c_{a}-\bar{a}\right)+(1-\eta) \log \left(c_{n}\right), \\
\text { s.t. : } \quad & p_{a} c_{a}+c_{n}=w\left(1-N_{a}\right)+N_{a} \int_{S} \pi(s) d F(s)+r K+q L, \\
& c_{a}>\bar{a}, c_{n} \geq 0 .
\end{aligned}
$$

The representative firm in non-agriculture chooses the amount of capital $\left(K_{n}\right)$ and labor $\left(N_{n}\right)$ to maximize profit, i.e.,

$$
\begin{aligned}
\max _{\left\{K_{n}, N_{n}\right\}} & A K_{n}^{\alpha} N_{n}^{1-\alpha}-r K_{n}-w N_{n} \\
\text { s.t. : } & K_{n} \geq 0, N_{n} \geq 0 .
\end{aligned}
$$

The factors market clearing conditions are

$$
\begin{aligned}
K_{n}+N_{a} \int_{S} k(s) d F(s) & =K, \\
N_{a}+N_{n} & =1, \\
N_{a} \int_{S} \ell(s) d F(s) & =L .
\end{aligned}
$$

The goods market clearing conditions are

$$
\begin{aligned}
c_{a} & =N_{a} \int_{S} y_{a}(s) d F(s), \\
c_{n} & =A K_{n}^{\alpha} N_{n}^{1-\alpha} .
\end{aligned}
$$

Equilibrium A competitive equilibrium is a collection of prices $\left\{w, r, q, p_{a}\right\}$, allocation for farmer operators $\{k(s), \ell(s)\}$, allocation for the representative firm in non-agriculture 
$\left\{K_{n}, N_{n}\right\}$, and allocation for the stand-in household $\left\{N_{a}, c_{a}, c_{n}\right\}$ such that (i) given prices, $\{k(s), \ell(s)\}$ solve farmer operators' problem in (1); $\left\{N_{a}, c_{a}, c_{n}\right\}$ solve household's optimization in (2); and $\left\{K_{n}, N_{n}\right\}$ solve firm's problem in (3); (ii) markets clear, i.e., equations (4) - (8) hold.

Determinant of Farm Size What determines farm size and its change over time in the model? Since the distribution of managerial skills is not changing over time, I can restrict my attention to factors affecting the optimal land size for a given farm operator. The optimal farm size for an operator with managerial skill $s$ is

$$
\ell(s)=\left(p_{a} A \kappa\right)^{\frac{1}{1-\gamma}}\left(\frac{\gamma(1-\theta)}{q}\right)^{\frac{1}{1-\gamma}} \Phi(s)^{\frac{\gamma-\rho}{\rho(1-\gamma)}}
$$

where

$$
\Phi(s)=\theta\left(\frac{\theta q}{(1-\theta) r}\right)^{\frac{\gamma}{1-\gamma}}+(1-\theta) s^{\frac{\rho}{1-\rho}} .
$$

For discussion suppose that $0<\rho<\gamma<1$, it follows that the optimal farm size is increasing in managerial skill $s$. Therefore, in equilibrium the model generates a nondegenerate distribution of farms with different land sizes. Over time, farm size increases when there is technological progress, either in aggregate TFP $(A)$ or in agricultural-specific efficiency $(\kappa)$. Expansion in farm size could also be fueled by cheaper land or cheaper capital. Therefore, the accumulation of land and capital over time could also drive the growth in farm size. Note, however, that in the production technology there is complementarity between managerial skill and land, but substitutability between managerial skill and capital. The implication is that as rental prices of land and capital fall over time, both land and capital are shifting from low-skill operators to high-skill operators, but at a faster pace for land relative to capital. As will be seen in section 4.2, this is indeed a salient feature of the data. 


\section{Quantitative Analysis}

\subsection{Calibration}

I calibrate the model to 1900 U.S. data. Let one model period correspond to 10 calendar years. I start by describing parameters whose values can be determined without solving the model. For technology in non-agriculture, let capital share $\alpha=1 / 3$. For technology in agriculture, let capital share $\theta=0.89$. These values are based on estimates of factor income shares for agriculture and non-agriculture from Valentinyi and Herrendorf (2008). The spanof-control parameter $\gamma=0.54$, and the elasticity parameter $\rho=0.24$. These values are taken directly from Adamopoulos and Restuccia (2014b). In particular, the elasticity parameter $\rho$ is less than unity, implying that capital and land are gross substitutes. The implication is that capital-land ratio decreases with farm size, as in the data. Let the weight on agricultural consumption $\eta=0.01$. This value implies a long-run share of expenditure on agricultural consumption that is commonly assumed in the literature. See, for example, Gollin et al. (2007) and Restuccia et al. (2008). Aggregate TFP $(A)$ and relative efficiency $(\kappa)$ are both normalized to 1 .

Managerial skills are assumed to follow a log-normal distribution with mean $\mu$ and vari-

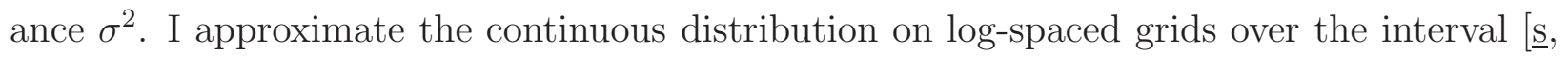
$\bar{s}$. The support is chosen such that $\underline{\mathrm{S}}$ is arbitrarily close to zero, and $\bar{s}$ is sufficiently large to guarantee a non-zero mass of farms above 400 hectares. There remains five parameters whose values are to be determined jointly: the distributional parameters $(\mu, \sigma)$, subsistence consumption parameter $(\bar{a})$, the aggregate quantity of capital $(K)$, and the quantity of land $(L)$. These parameters are chosen to match the following moments in the data for 1900: (i)

the share of labor in agriculture (0.4); (ii) aggregate capital-output ratio (3.1); (iii) average farm size in hectares (59.3); and (iv) the size distribution of farms. Table 1 summaries the parameter values and their source of identification.

Figure 3 shows the farm size distribution in the model and in the data for the year 1900. Panel (a) plots the frequency of farms by size group. As can bee seen, the calibration produces a good fit to the size distribution in the data. In addition, the model does well 
Table 1: Parameter Values and Calibration Targets

\begin{tabular}{clll}
\hline Parameter & Description & Value & Source of Identification \\
\hline Endowment & & & \\
L & Land per worker & 14.6 & Mean farm size \\
K & Capital per worker & 5.99 & Capital-output ratio \\
Technology & & & \\
$A$ & TFP & 1 & Normalization \\
$\kappa$ & Agriculture-specific efficiency & 1 & Normalization \\
$\alpha$ & Capital share, Non-agriculture & $1 / 3$ & Valentinyi and Herrendorf (2008) \\
$\theta$ & Capital share, Agriculture & 0.89 & Valentinyi and Herrendorf (2008) \\
$\rho$ & Elasticity of substitution & 0.24 & Adamopoulos and Restuccia $(2014 \mathrm{~b})$ \\
$\gamma$ & Span-of-control & 0.54 & Adamopoulos and Restuccia $(2014 \mathrm{~b})$ \\
Preferences & & & \\
$\eta$ & Consumption weights & 0.01 & Long-run expenditure shares \\
$\bar{a}$ & Minimum consumption & 1.56 & Share of labor in agriculture \\
$\mu$ & & & \\
$\sigma$ & Mean & -0.83 & Farm size distribution \\
Farm Productivity & Standard Deviation & 6.67 & Farm size distribution \\
\hline
\end{tabular}

replicating other non-targeted moments in the data. Panel (b) plots the distribution of land by farm size. A noticeable pattern is the distribution of land across farms is highly skewed - large farms account for close to 35 percent of total all land in farms, despite the fact that they account for less than 5 percent of all farms. Panel (c) plots the distribution of capital by farm size. Large farms account for a much smaller fraction of total capital, relative to land. It follows immediately that capital-land ratio declines with farm size. This is confirmed in panel (d). Finally, panel (e) shows that the calibrated model is also able to capture the disparity in value added per worker across size categories.

\subsection{Factor Endowment and Technology}

In sections below, I use the calibrated model to evaluate quantitatively important factors driving long-term changes in farm size distribution. The model has four exogenous processes: aggregate TFP, agriculture-specific efficiency, stock of capital, and stock of land. A natural starting point is to assess whether the growth in these aggregate factors can generate farm size growth as observed in the data.

For this purpose, I obtain long-run data on real GDP per worker, physical and human 
capital per worker, and land per worker from Turner, Tamura, and Mulholland (2008). These data are available centennially from 1900 to 2000. From this data, I calculate the growth rate of physical capital per worker and land per worker. With calibrated initial values for the aggregate stock of capital $(K)$ and land $(L)$, I construct the entire sequence of capital and land per worker. To construct aggregate TFP, I use the data on real GDP per worker, physical capital per worker, and human capital per worker and impute aggregate TFP as a Solow residual, following the standard development accounting methods in Hall and Jones (1999) and Caselli (2005).

TFP for the agricultural sector is available from Kendrick (1961) up to 1950. After that, estimates are available from the United States Department of Agriculture (USDA). Dividing the TFP series for agriculture by the aggregate TFP series then yields the sequence of agriculture-specific efficiency $\kappa$. Table 2 summaries these exogenous variables. It is immediately observed from the table that there is little growth in TFP prior to 1940, for either the agricultural sector or the aggregate economy. From 1940 to 2000, TFP growth in agriculture is faster than that in the aggregate by roughly one percent annually. In other words, agriculture-specific efficiency $\kappa$ is constant prior to 1940, and then grows one percent annually after 1940 .

Table 2: Annualized Growth of GDP per worker and TFP

\begin{tabular}{lccc}
\hline & $1900-2000$ & $1900-1940$ & $1940-2000$ \\
\hline GDP per worker & 1.65 & 1.21 & 1.84 \\
TFP, aggregate & 0.63 & -0.05 & 0.92 \\
TFP, agriculture & 1.41 & 0.06 & 1.99 \\
\hline
\end{tabular}

Given these exogenous processes, the model endogenously generates implications about employment and output in agriculture and non-agriculture, relative prices of output between agriculture and non-agriculture, size distributions of farms, and distributions of capital, land, and output across farms. I confront each of these implications with data in sections below.

Employment, Productivity and Prices In the model, labor moves out of agriculture over time as income increases and expenditure shifts away from consumption goods produced in agriculture. Quantitatively, starting from 40 percent in 1900, the model predicts that 
the share of labor in agriculture declines continually to 5 percent by 2000 - see panel (a) of Figure 4. This is a 35 percentage point decline, relative to 38 in the data. Therefore, the model explains about 90 percent of the observed decline in the share of labor in agriculture. Put differently, the share of labor in agriculture declines at an annual rate of 2 percent in the model, compared to 3 percent in the data.

In the data, real value added per worker in agriculture increased at an annual rate of 3 percent from 1900 to 2000. Upon closer inspection, this productivity growth occurred almost exclusively after 1930 - see panel (b) of Figure 4. The model is able to replicate this pattern of productivity growth, but is less able to match the fast productivity growth in the latter half of the sample period. In the model, real value added per worker in agriculture increases 2.3 percent annually. In addition, the model is able to reproduce almost all of the growth in per worker GDP over the period - see panel (c) of Figure 4.

The migration of labor out of agriculture is accompanied by the fall in the price of output in agriculture relative to non-agriculture. Panel (d) of Figure 4 shows that this implication is consistent with the data. Historical producer prices for farm product and industrial product are available from Hanes (2006). I compute the relative price in the data as the price of farm product relative to the price of industrial product. Between 1900 and 2000, the relative price of agricultural output declined by roughly a factor of 2 . The model is able to reproduce all the decline in the relative price. As is standard in the structural change literature, labor migration out of agriculture in the model is driven by two mechanisms: non-homothetic preferences and sector-biased technological changes. However, these two mechanisms have different implications about relative prices along the path of development: the first one implies rising relative price of agricultural output and the second one falling. The results of the model suggest that the second mechanism dominates.

Farm Size Distribution I now turn to the model's implications about farm size distribution. Can these aggregate factors explain also the changes in the composition of farms over time? One of the most notable trends in the data is the increasing average farm size over time. In the model, the production technology in agriculture implies one operator per farm, hence the measure of farm operators in the model is identical to the measure of farms. 
In this case, average farm size is simply the quantity of land per worker divided by the share of labor in agriculture. The exogenous quantity of land per worker is declining over time, but the share of labor in agriculture is declining at a faster rate in the model. Therefore, average farm size in the model increases from 60 hectares in 1900 to 145 hectares in 2000 see Figure 5. This increase is somewhat slower compared to the actual one. ${ }^{6}$

The increase in mean farm size is the result of changes in the composition of farms. For exposition purpose, I focus on farms in two size groups: small and large. Small farms are those with land below 20 hectares, and large farms are those with land above 200 hectares. Table 3 shows the shares of small and large farms over time. On the one hand, the model is able to replicate the sharp increase in the share of large farms from 3 percent in 1900 to 17 percent in 2000. On the other hand, the model predicts a counterfactual decline in the share of small farms, which has remained constant over time in the data.

Table 3: Share of Farms by Size

\begin{tabular}{ccccc}
\hline Year & \multicolumn{2}{c}{ Farms } & $<20 \mathrm{Ha}$ & \multicolumn{2}{c}{ Farms } & $>200 \mathrm{Ha}$ \\
& Data & Model & Data & Model \\
\hline 1900 & 0.34 & 0.36 & 0.03 & 0.05 \\
1920 & 0.36 & 0.41 & 0.03 & 0.03 \\
1940 & 0.38 & 0.30 & 0.04 & 0.05 \\
1960 & 0.29 & 0.17 & 0.09 & 0.09 \\
1980 & 0.28 & 0.15 & 0.16 & 0.09 \\
2000 & 0.35 & 0.06 & 0.16 & 0.17 \\
\hline
\end{tabular}

Small farms, despite the continued presence, are accounting for a declining share of total land in agriculture. Their share of all land in farms declined from 6 percent in 1900 to 2 percent in 2000. Land released from small farms are absorbed by large ones. Table 4 shows that large farms accounted for one third of total land in 1900, and almost 80 percent by 2000. The model captures all of the decline in the share of land accounted for by small farms, and is able to account for about two thirds of the increase in the share of land accounted for by large farms.

Table 5 shows that the changes in the allocation of capital across farms are considerably

\footnotetext{
${ }^{6}$ The two kinks in the figure are associated with significant drop in land per worker in the 1930s (great depression) and the 1980s (farm credit crisis).
} 
Table 4: Share of Land by Size

\begin{tabular}{ccccc}
\hline Year & \multicolumn{2}{c}{ Farms } & $20 \mathrm{Ha}$ & \multicolumn{2}{c}{ Farms } & $>200 \mathrm{Ha}$ \\
& Data & Model & Data & Model \\
\hline 1900 & 0.06 & 0.07 & 0.37 & 0.35 \\
1920 & 0.05 & 0.10 & 0.41 & 0.27 \\
1940 & 0.05 & 0.06 & 0.45 & 0.33 \\
1960 & 0.02 & 0.03 & 0.66 & 0.43 \\
1980 & 0.01 & 0.02 & 0.71 & 0.42 \\
2000 & 0.02 & 0.01 & 0.79 & 0.57 \\
\hline
\end{tabular}

different from those of land. The most obvious difference is that the share of capital sitting in small farms displays little variation over time - from 13 percent in 1900 to 12 percent in 2000. This contrasts with the declining share of land in small farms shown in Table 4. This reflects the fact that on a per acre basis, small farms are more capital intensive than large farms. Like in the case of land, large farms are accounting for a increasingly larger share of total capital in agriculture, from 11 percent to 50 percent. The model cannot fully account for these features of capital allocation across farms in the data. For small farms, the model predicts a counterfactual decline in its share of total capital to 4 percent by 2000 . For large farms, the model is able to generate about half of the increase in its share of total capital.

Table 5: Share of Capital by Size

\begin{tabular}{ccccc}
\hline Year & \multicolumn{2}{c}{ Farms $<20 \mathrm{Ha}$} & \multicolumn{2}{c}{ Farms } \\
& Data & Model & Data & Model \\
\hline 1900 & 0.13 & 0.25 & 0.11 & 0.13 \\
1920 & 0.11 & 0.31 & 0.11 & 0.09 \\
1940 & 0.11 & 0.09 & 0.16 & 0.20 \\
1980 & 0.09 & 0.11 & 0.44 & 0.17 \\
2000 & 0.12 & 0.04 & 0.50 & 0.28 \\
\hline
\end{tabular}

As productive resources like capital and land are reallocating from small to large farms, so is output. Data on output by farm size is not available until 1940, therefore I focus on these statistics after 1940. In the model, the share of output accounted for by small farms declines from 12 percent in 1940 to 3 percent in 2000, whereas the share of output accounted for by large farms increases from 20 percent to 44 percent. Again, such reallocation is considerably slower in the model relative to the data. For example, the share of output accounted for by 
large farms increases from 20 percent in 1940 to 58 percent in 2000 in the data. Hence, the model captures about two-thirds of the increase in the share of output produced by large farms.

To sum up, the findings so far are two-fold. On the one hand, factor endowment and technological progress account for most of the decline in employment and the increase in value added per worker in agriculture. One the other hand, these aggregate factors explain much less of the changes in the composition of farms by size. In particular, the model with factor endowment and technological change alone misses two salient features of the farm size distribution observed in the data, namely (i) the stagnation of small firms both in terms of numbers and their share of capital and output; and (ii) the rapid concentration of capital, land, and output in farms at the upper end of the size distribution. These results lead to the next question: what else can explain these features of the farm size distribution?

\subsection{Policy Distortions}

In this section, I focus on policies that distort optimal farm size as another source of longterm changes in farm size distribution. Ever since the Agricultural Adjustment Act (1933), government subsidies have been a permanent feature of U.S. agriculture. U.S. farm policies are complex in scope and implementation; for a review, see Gardner (2006) and Sumner et al. (2010). It remains a debate in the literature how farm policies have influenced farm size. Key and Roberts (2007) argue that pro-large farm policies are the most important factor behind farm consolidation, while others like Sumner (2014) remain skeptical about the casuality. One key aspect that separates this paper from previous research is the ability to evaluate systematically the role of policy distortions in an equilibrium model. As will be clear soon, the farm-level statistics constructed from census of agriculture are crucial for identifying such distortions to farm size and their changes over time.

The key hypothesis proposed here is that farm policies distort the optimal farm size, and therefore affect the long-term changes in farm size distribution. More importantly, such distortions vary across farms of different land sizes. I begin by presenting some evidence that

suggests farm policies in the U.S. are implicitly or explicitly size-dependent. An example 
of explicit size-dependent policies could be located in the 2008 Farm Bill, which stipulated that farms below 10 acres are not eligible to receive a direct, counter-cyclical payment unless the farm is owned by a socially disadvantaged or limited resources farmer or rancher. Other policies are less obvious in their size-dependent nature. A prominent feature of U.S. farm policies is that the majority of subsidies are directed towards the so-called "program crops" such as cotton, wheat, soybeans and upland cotton. Between 1995 and 2012, these crops accounted for 85 percent of all direct payments from the government. ${ }^{7}$ Since farms producing these "program crops" tend to operate with a much larger plot of land, it follows that the direct payment system has a built-in size-dependent feature. This is also reflected in the distribution of direct payments across farm sizes. In 2002, farms above 200 hectares account for 72 percent of all direct payments from the government, compared to less than 2 percent for farms below 20 hectares. Crop insurance is gradually replacing direct payment as the main instrument for farm subsidies, but the same pattern holds. Farms above 200 hectares account for 87 percent of all crop insurance payments in 2002, compared to 10 percent to farms below 20 hectares.

Other policies do not have a built-in size-dependent feature, but nevertheless de facto favor large farms. Farming in modern days requires large investment in machinery, equipments, and other capital. Therefore, the tax treatment of these investment is of considerable importance to farmers. The income tax code allows farmers to expense up to a certain portion of capital investment per year. For example, in 2000 the nominal limit is $\$ 20,000$ dollars. To see this in perspective, USDA reports that average capital expenditure for all farms is $\$ 10,604$ measured in 2002 U.S. dollars. Thus the capital cost recovery system likely benefits large farms more, as they typically have larger capital investment or carry a larger tax liability to take full advantage of the allowance. Therefore, larger farms might as a result have lower capital costs as argued in Key and Roberts (2007). Lower capital cost then leads to farm size growth as articulated in Kislev and Peterson (1982).

The focus of this paper is not to evaluate specific policies. Instead, I follow the strategy in Restuccia and Rogerson (2008) and model distortions to optimal size as ad volrem taxes on

\footnotetext{
${ }^{7}$ Data from the EWG farm subsidy database, available at http://farm.ewg.org/index.php.
} 
output. Negative taxes are interpreted as subsidies. As in Restuccia and Rogerson (2008), these taxes are allowed to correlate with managerial skills and in equilibrium with farm size. Let $\operatorname{tax} \tau(s)$ denote the tax on output facing a farm operator with managerial skill $s$. Her problem is now the following:

$$
\begin{gathered}
\max _{\{k, \ell\}}(1-\tau(s)) p_{a} A \kappa\left[\theta k^{\rho}+(1-\theta)(s \ell)^{\rho}\right]^{\frac{\gamma}{\rho}}-r k-q \ell \\
\text { s.t. : } \quad k \geq 0, \ell \geq 0 .
\end{gathered}
$$

There is a government that collects taxes, and reimburses tax proceeds back to the household via lump-sum transfers. The optimization problem of the stand-in household is now

$$
\begin{aligned}
\max _{\left\{N_{a}, c_{a}, c_{n}\right\}} & \eta \log \left(c_{a}-\bar{a}\right)+(1-\eta) \log \left(c_{n}\right), \\
\text { s.t. : } & p_{a} c_{a}+c_{n}=w\left(1-N_{a}\right)+N_{a} \int_{S} \pi(s) d F(s)+r K+q L+T R, \\
& c_{a}>\bar{a}, c_{n} \geq 0 .
\end{aligned}
$$

where $T R$ is the lump-sum transfer from the government. The government balances its budget, which requires

$$
T R=N_{a} \int_{S} p_{a} y_{a}(s) \tau(s) d F(s)
$$

Inferring Farm-size Distortions To simplify the analysis, I assume that the economy is frictionless prior to 1940. This timing is consistent with the introduction of the Agricultural Adjustment Act in 1933. This assumption has an added benefit that the calibration of the model remains the same. Since these taxes do not have a direct empirical counterpart, for the period between 1940 and 2000 I need to estimate the distribution of taxes. The strategy is to use the model, together with the observed farm size distribution, to infer the distribution of taxes. Specifically, the sequences of aggregate TFP, agriculture-specific efficiency, capital per worker, and land per worker remain the same same as in the frictionless economy. Given 
these exogenous processes, I pick the distribution of taxes, $\{\tau(s)\}$, such that the model generates exactly the same size distribution of farms as in the data, for every period starting from 1940. In other words, with farm-size distortions the model now by construction explains all of the changes in the size distribution of farms.

I assume a non-parametric distribution for the taxes. Since the distribution of managerial skills is approximated over 6000 discrete points, this amounts to choosing 6000 different tax rates. To ease computation, I instead estimate a vector of taxes $\left\{\tau_{j}\right\}_{j=1}^{J}$ over a smaller subset of managerial skills $\left[s_{1}, s_{2} \ldots s_{J}\right]$, with $J=10, s_{1}=\underline{s}$ and $s_{J}=\bar{s}$. I then linearly interpolate this vector of taxes $\left\{\tau_{j}\right\}$ over the full set of managerial skills $[\underline{s}, \bar{s}]$. For each period, the program searches for the vector $\left\{\tau_{j}\right\}_{j=1}^{J}$ such that the model produces equilibrium size distribution of farms that exactly matches its data counterpart. Table 6 summarizes allocations in the distorted economy, alongside with those from the frictionless economy.

Table 6: Aggregate and Farm-level Allocations

\begin{tabular}{lccc}
\hline & Data & Frictionless & Distorted \\
\hline Growth of aggregate variables & & & \\
& & & \\
Share of labor in agriculture & -3.11 & -2.09 & -2.05 \\
Output per worker in agriculture & 2.97 & 2.27 & 2.23 \\
GDP per worker & 1.64 & 1.48 & 1.47 \\
& & & \\
Farm-level allocations in 2000 & & & \\
& & & \\
Farms below 20 hectares & 1.6 & 1.0 & 2.5 \\
\hline Share of land & 12 & 4.0 & 10 \\
Share of capital & 10 & 3.0 & 8.7 \\
Share of output & & & \\
& & & \\
Farms above 200 hectares & 78 & 56 & 76 \\
Share of land & 50 & 28 & 52 \\
Share of capital & 58 & 44 & 58 \\
Share of output &
\end{tabular}

Two observations are immediate from the Table 6. I start with comparing aggregate allocations between the distorted economy and the frictionless economy. I focus on three aggregate variables: the share of labor in agriculture, real value added per worker in agriculture, and aggregate GDP per worker. Qualitatively, the distorted economy has slower labor 
migration out of agriculture, as well as slower productivity growth in agriculture and in the aggregate. Quantitatively, however, these effects are negligible. This is confirmed in Figure 6 , which plots the time paths of these variables.

The distortions to farm size, however, have a much more pronounced distributional effect. Note again that the model by construction reproduces the changes in the size distribution of farms. Nevertheless, the model's predictions about the distribution of capital, land, and output across farms are testable implications. Table 6 shows that these predictions from the model are quantitatively consistent with the data. In particular, the model with farmsize distortions captures two salient features of the data that the model with only aggregate factors cannot. Relative to the data, the frictionless model predicts too fast a decline in the share of productive resources accounted for by small farms, and simultaneously too slow an increase in the share accounted for by large farms. The model with farm-size distortions get both margins right - it generates allocations of land, capital, and output between small and large farms that look nearly identical to those in the data.

Another way to illustrate the distributional effects of farm-size distortions is to look at the Lorenz curve of capital, land, and output. Figure 7 plots these Lorenz curves for the year 2002. Two properties of the distorted economy stand out from the figure: (1) the distribution of capital, land, and output from the distorted economy is close to that in the data; (2) without distortions to farm size, the frictionless economy cannot reproduce the concentration of resources in large farms. I further explore the effects of farm-size distortions in the time series. Figure 8 plots the Gini coefficients of land, capital, and output. In the data, the Gini coefficients increase over time, and the frictionless model is not able to generate such an increase. In contrast, adding farm-size distortions to the frictionless economy could generates rising inequality that looks similar to that in the data.

Why, then, do distortions to farm size have little effect on employment and value added per worker in agriculture? This has to do with both the shape and the magnitude of these distortions. Figure 9 plots $(1-\tau(s))$ by farm size in the model. The outstanding feature is the "regressiveness" of these distortions, i.e., the rate of subsidy increases with farm size. This form of regressive taxes is necessary for the model to generate the continued presence 
of small farms and simultaneously the rapid concentration of resources in large farms. These taxes and subsidies have two opposing effects on output. On the one hand, taxing small farms reduces output directly. On the other hand, the subsidies to large farms effectively reallocate resources from less-productive small farms to large farms that are more productive. The gain through reallocation offsets the productivity loss due to taxes. Aggregating over all farms, agriculture is a net recipient of subsidies. As a share of agricultural value added, these subsidies average about 6 percent. Given the small magnitude of these subsidies, it is not surprising to observe that they have little effect on agricultural employment and productivity.

\section{Conclusion}

The transformation of U.S. agriculture over the 20th century is remarkable in many ways. This paper focuses on one aspect of it: the increasing dominance of large farms. In particular, it assesses quantitatively with an equilibrium model the importance of factor endowment and technological progress, relative to policy distortions, in driving long-term changes in farm size distribution. The findings are two-fold. On the one hand, the decline in employment and the growth in value added per worker in agriculture is almost entirely driven by the accumulation of capital and land, and the improvement in technology. These aggregate factors alone, however, cannot explain fully why large farms have been increasingly dominant over time. On the other hand, the model suggests that farm policies that distort optimal farm size are a more important force behind the "rise of large farms." These farm-size distortions are regressive and substantially alter the allocation of productive resources across farms; yet they are borderline irrelevant for aggregate outcomes.

The implications of this paper are clear. It echoes with popular hypothesis among the public that farm policies are "pro-large." For those who are concerned about inequality within the farm sector, farm policies are more to blame than technology. For those who are concerned about productivity growth in agriculture, farm policies are borderline irrelevant.

The limitations of the paper are also clear. By using a highly aggregated model, this paper from the onset abstracts from other dimensions that are potentially important. An example is the cross-state difference in farm size distribution, and the correlation with difference 
in crop composition, land quality, climate, and state-specific farm policies. The census of agriculture contains information that is rich enough to allow incorporating these dimensions into the analysis. This is left for future research.

\section{References}

Adamopoulos, T. and D. Restuccia (2014a). Land Reform and Productivity: A Quantitative Analysis with Micro Data. University of Toronto Working Paper.

Adamopoulos, T. and D. Restuccia (2014b). The Size Distribution of Farms and International Productivity Differences. American Economic Review 104(6), 1667-97.

Bento, P. and D. Restuccia (2015). Misallocation, establishment size, and productivity. Working papers, University of Toronto, Department of Economics.

Cai, W. and M. Pandey (2013). Size-Dependent Labor Regulations and Structural Transformation in India. Economics Letters 119(3), 272-275.

Caselli, F. (2005). Accounting For Cross Country Income Differences. In P. Aghion and S. D. Durlauf (Eds.), Handbook of Economic Growth, pp. 679-741. ELSEVIER.

Dimitri, C., A. Effland, and N. C. Conklin (2005). The 20th Century Transformation of U.S. Agriculture and Farm Policy. Economic Information Bulletin 59390, United States Department of Agriculture, Economic Research Service.

Garcia-Santana, M. and J. Pijoan-Mas (2014). The Reservation Laws in India and the Misallocation of Production Factors. Journal of Monetary Economics 66(0), 193 - 209.

Gardner, B. (2006). American Agriculture in the Twentieth Century: How it Flourished and what it Cost. Harvard University Press.

Gardner, B. L. (1992). Changing Economic Perspectives on the Farm Problem. Journal of Economic Literature 30(1), 62-101. 
Garicano, L., C. LeLarge, and J. V. Reenen (2013, February). Firm Size Distortions and the Productivity Distribution: Evidence from France. Working Paper 18841, National Bureau of Economic Research.

Gollin, D., S. L. Parente, and R. Rogerson (2007). The Food Problem and the Evolution of International Income Levels. Journal of Monetary Economics 54 (4), 1230-1255.

Griliches, Z. (1963). The Sources of Measured Productivity Growth: United States Agriculture, 1940-60. Journal of Political Economy 71, 331.

Guner, N., G. Ventura, and Y. Xu (2008). Macroeconomic Implications of Size-Dependent Policies. Review of Economic Dynamics 11(4), 721-744.

Hall, R. E. and C. I. Jones (1999). Why Some Countries Produces So Much More Output per Worker Than Others. The Quaterly Journal of Economics 114(1), 83-116.

Hanes, C. (2006). Wholesale and producer price indexes, by commodity group: 1890?997 [Bureau of Labor Statistics]. Table Cc66-83 . In S. B. Carter, S. S. Gartner, M. R. Haines, A. L. Olmstead, R. Sutch, and G. Wright (Eds.), Historical Statistics of the United States, Earliest Times to the Present: Millennial Edition. New York: Cambridge University Press.

Hsieh, C.-T. and P. J. Klenow (2009). Misallocation and Manufacturing TFP in China and India. The Quarterly Journal of Economics 124(4), 1403-1448.

Huffman, W. E. and R. E. Evenson (2001). Structural and productivity change in us agriculture, 1950-1982. Agricultural Economics 24(2), 127-147.

Jorgenson, W. and F. M. Gollop (1992). Productivity Growth in U.S. Agriculture: A Postwar Perspective. American Journal of Agricultural Economics 74(3), 745-750.

Kendrick, J. W. (1961, October). Productivity Trends in the United States. NBER Books. National Bureau of Economic Research, Inc.

Key, N. D. and M. J. Roberts (2007). Commodity Payments, Farm Business Survival, and Farm Size Growth. Economic Research Report 55968, United States Department of Agriculture, Economic Research Service. 
Khaldi, N. (1975). Education and Allocative Efficiency in U.S. Agriculture. American Journal of Agricultural Economics 57(4), 650-657.

Kislev, Y. and W. Peterson (1982, June). Prices, Technology, and Farm Size. Journal of Political Economy $90(3), 578-95$.

Lucas, R. E. (1978). On the Size Distribution of Business Firms. Bell Journal of Economics $9(2), 508-523$.

MacDonald, J. M. (2011). Why Are Farms Getting Larger? The Case Of The U.S. 51st Annual Conference, Halle, Germany, September 28-30, 2011 115361, German Association of Agricultural Economists (GEWISOLA).

Manuelli, R. E. and A. Seshadri (2005). Human Capital and the Wealth of Nations.

Midrigan, V. and D. Y. Xu (2014). Finance and Misallocation: Evidence from Plant-Level Data. American Economic Review 104(2), 422-58.

Restuccia, D. and R. Rogerson (2008). Policy Distortions and Aggregate Productivity with Heterogeneous Plants. Review of Economic Dynamics 11(4), 702-720.

Restuccia, D. and R. Rogerson (2013). Misallocation and productivity. Review of Economic Dynamics 16(1), 1-10.

Restuccia, D. and R. Santaeulalia-Llopis (2014). Land Misallocation and Productivity. University of Toronto Working Paper.

Restuccia, D., D. T. Yang, and X. Zhu (2008). Agriculture and Aggregate Productivity: A Quantitative Cross-country Analysis. Journal of Moneytary Economics 55(2), 234-250.

Sumner, D. A. (2014). American Farms Keep Growing: Size, Productivity, and Policy. Journal of Economic Perspectives 28(1), 147-66.

Sumner, D. A., J. M. Alston, and J. W. Glauber (2010). Evolution of the Economics of Agricultural Policy. American Journal of Agricultural Economics 92(2), 403-423. 
Turner, C., R. Tamura, and S. Mulholland (2008). How important are human capital, physical capital and total factor productivity for determining state economic growth in the United States: 1840-2000? MPRA Paper 7715, University Library of Munich, Germany.

Valentinyi, A. and B. Herrendorf (2008). Measuring Factor Income Shares at the Sector Level. Review of Economic Dynamics 11(4), 820-835. 


\section{A Appendix}

Figure 1: Growth of Farm Size by Region

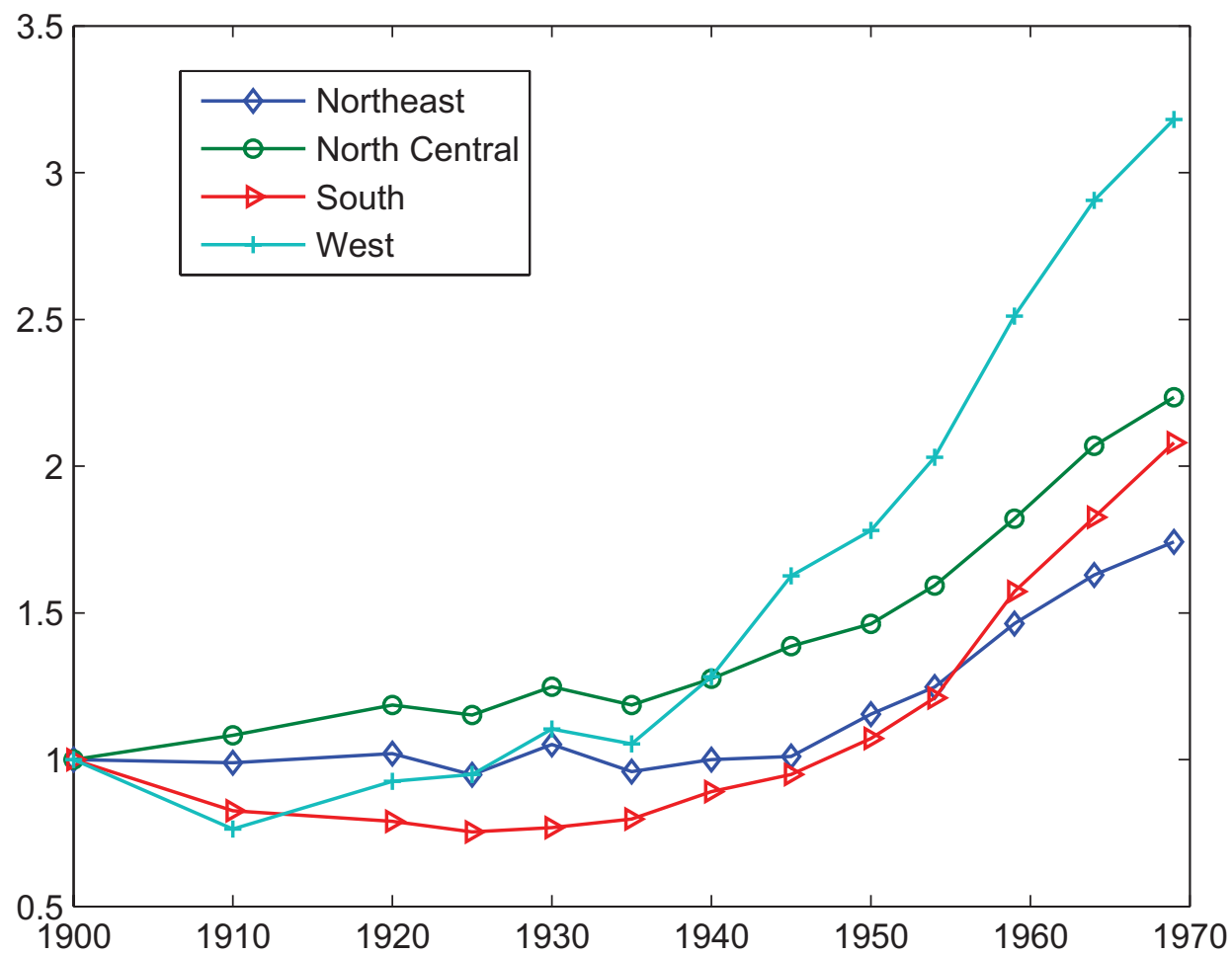

Note: Data is from Bicentennial Edition: Historical Statistics of the United States, Colonial Times to 1970, Census Bureau of the United States. For all regions, average farm size in 1900 is normalized to 1 . 
Figure 2: Labor Productivity by Farm Size (2002 Census)

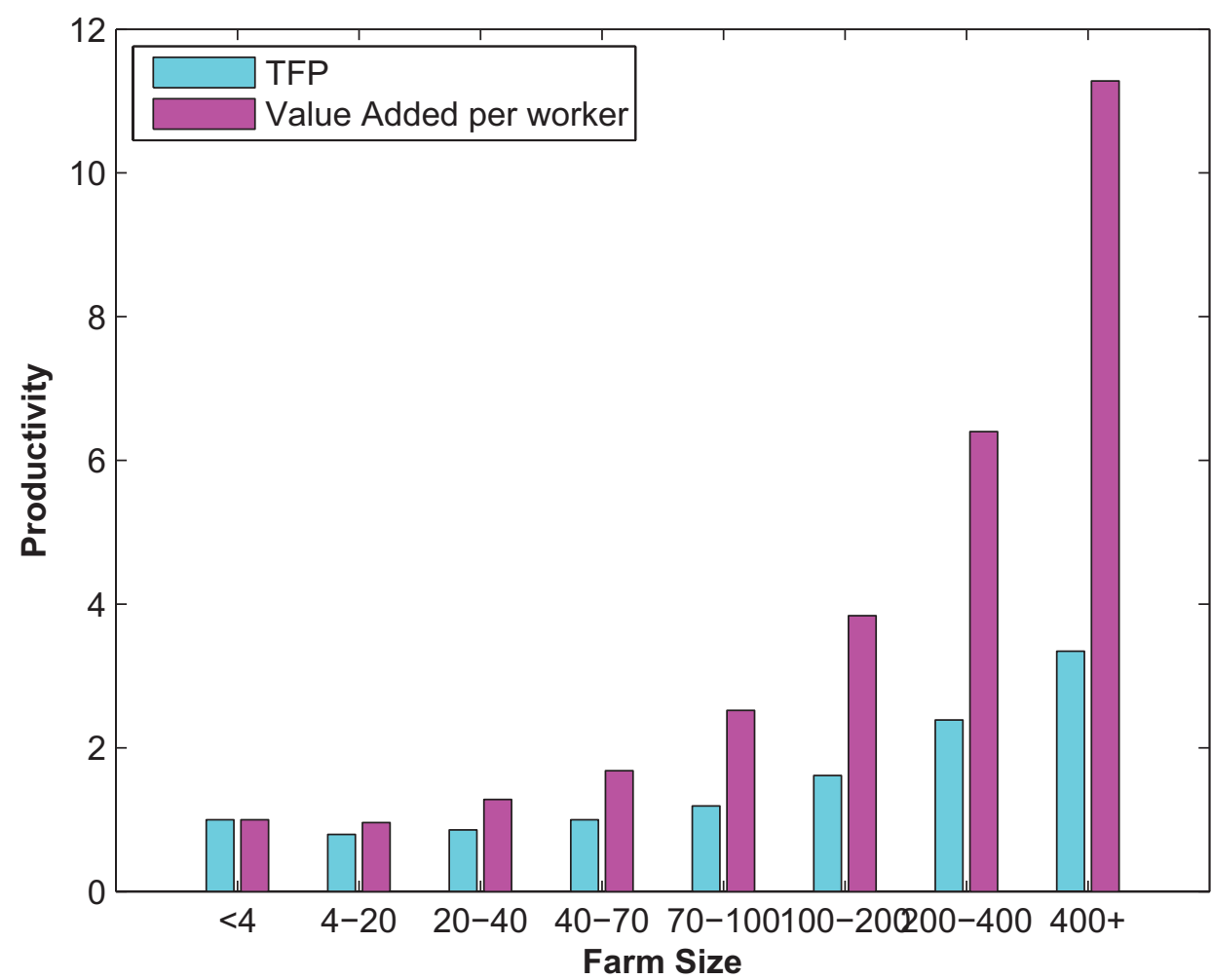


Figure 3: Model Fit: Farm Size Distribution

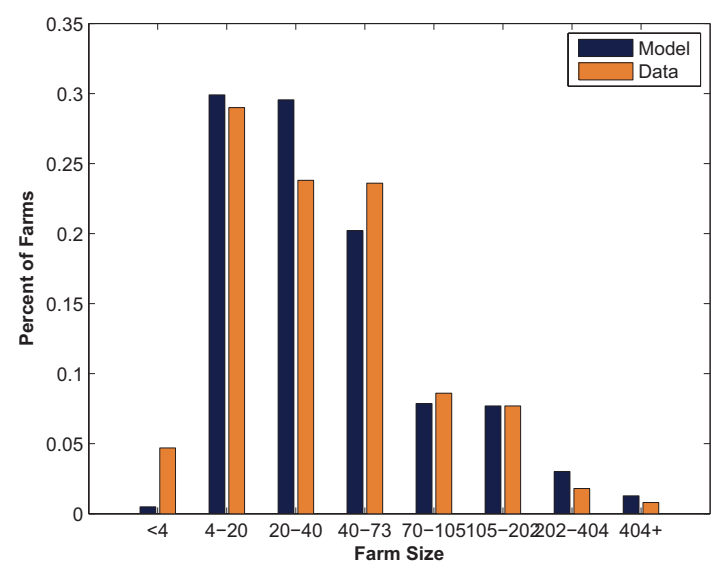

(a) Share of farms by size

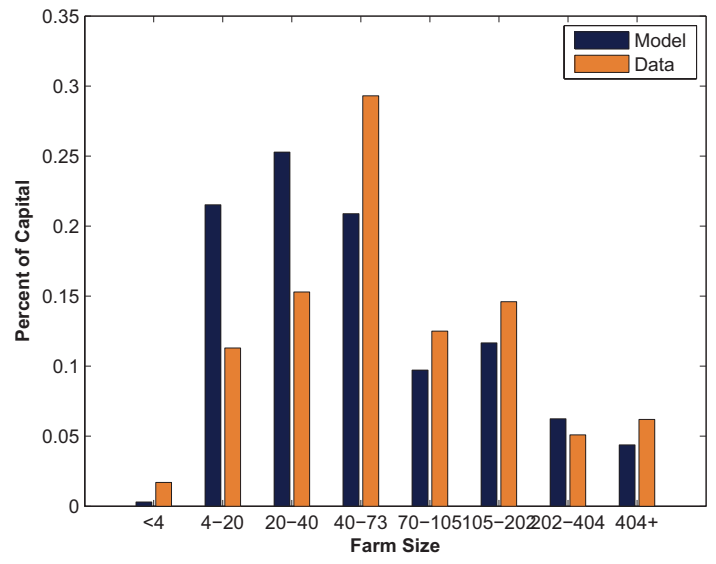

(c) Share of capital by size

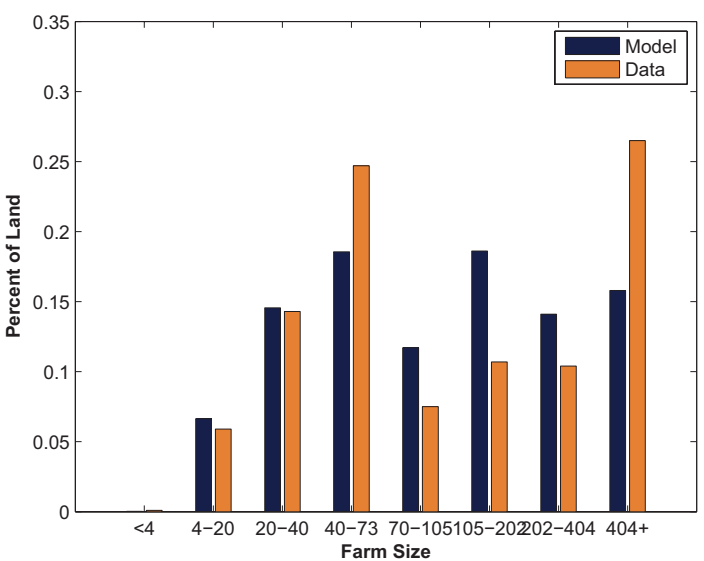

(b) Share of land by size

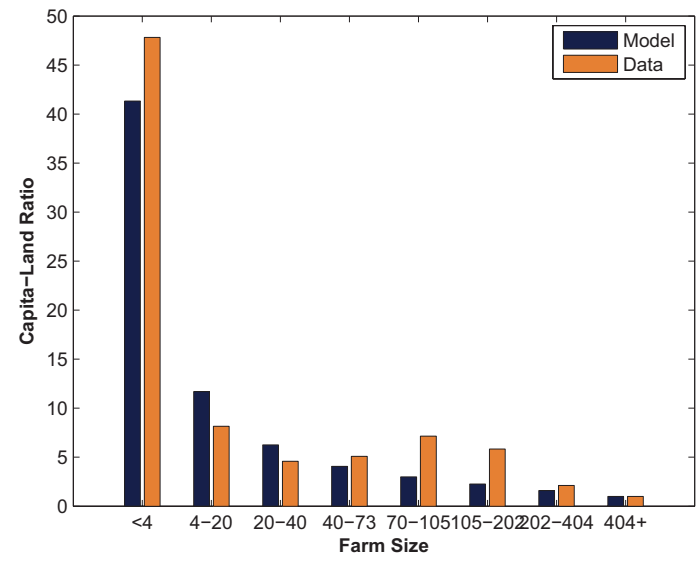

(d) Capital-Land ratio by size

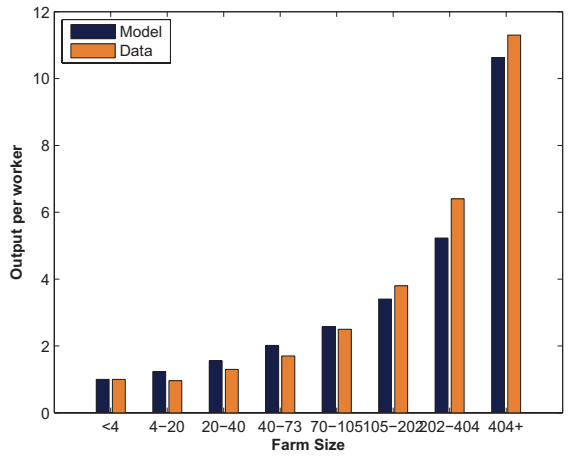

(e) Value added per worker by size 
Figure 4: Aggregate Allocations: Data versus Frictionless Economy

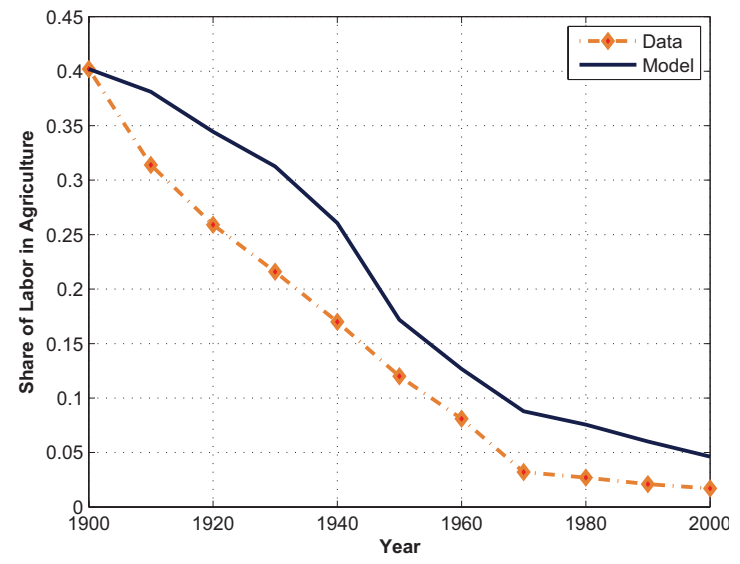

(a) Share of Labor in Agriculture

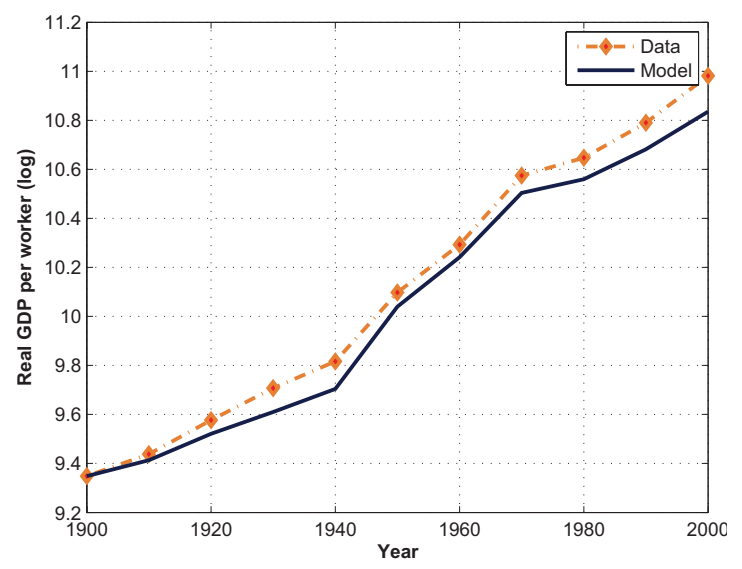

(c) Aggregate GDP per worker

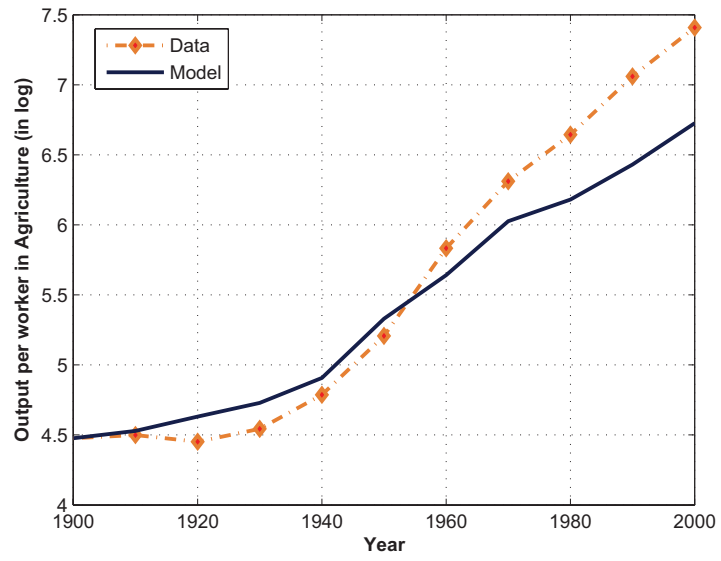

(b) Value Added per worker in Agriculture

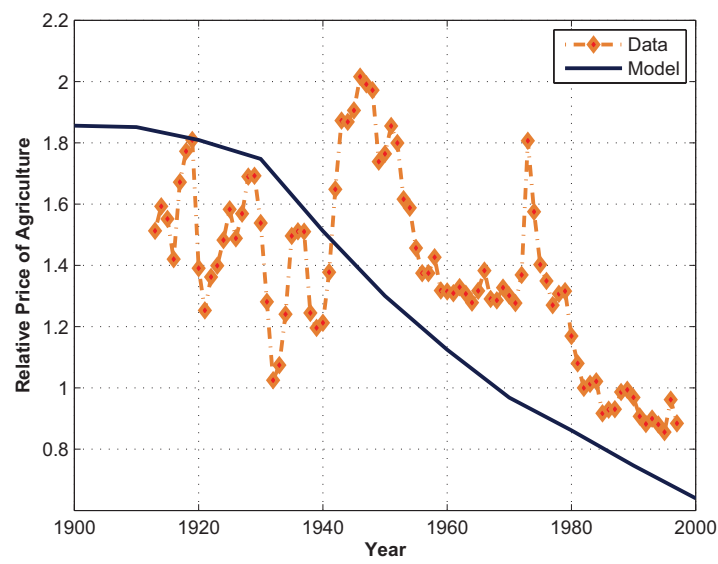

(d) Relative Price of Output 
Figure 5: Average Farm Size: Data versus Frictionless Economy

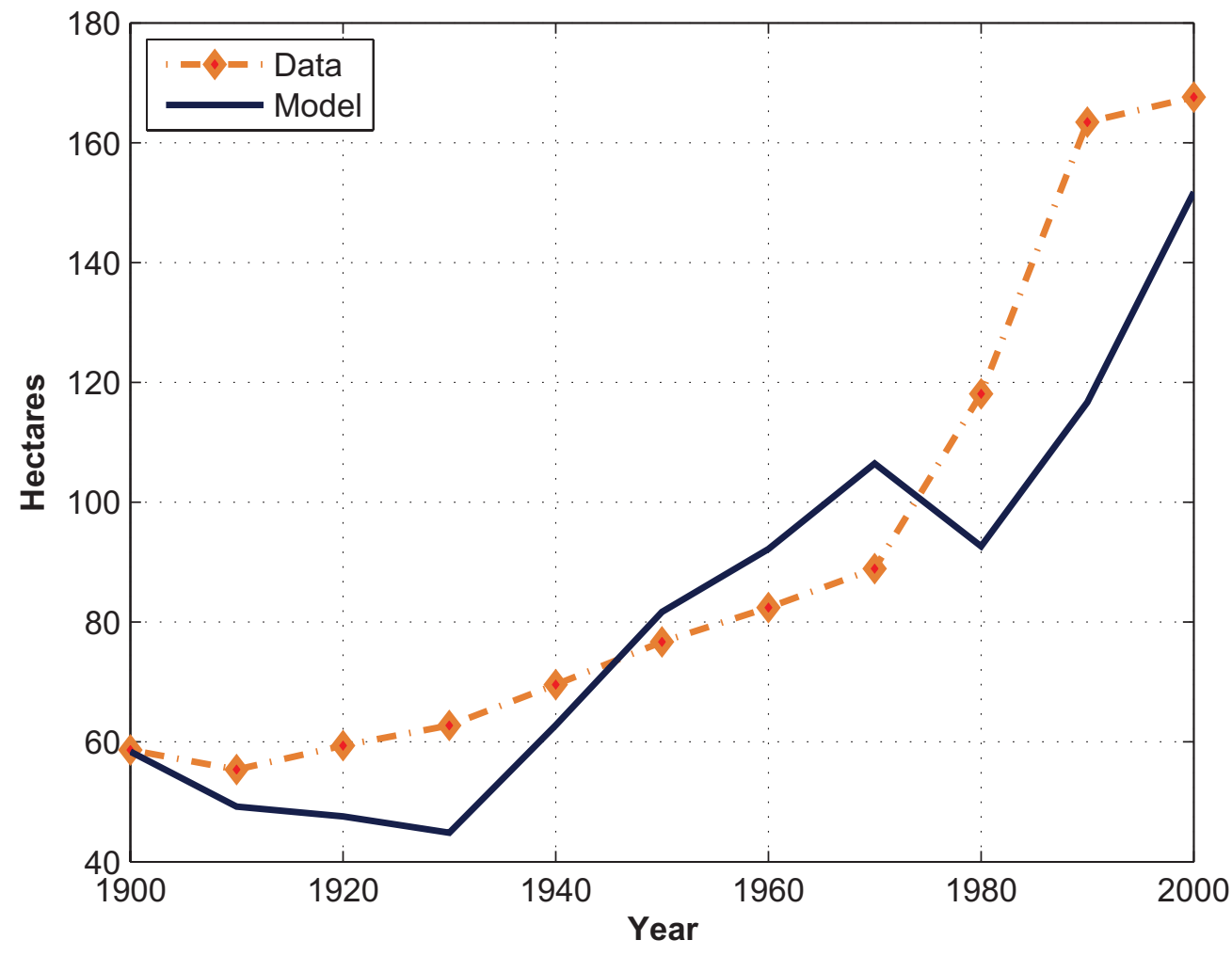


Figure 6: Aggregate Allocations: Frictionless versus Distorted

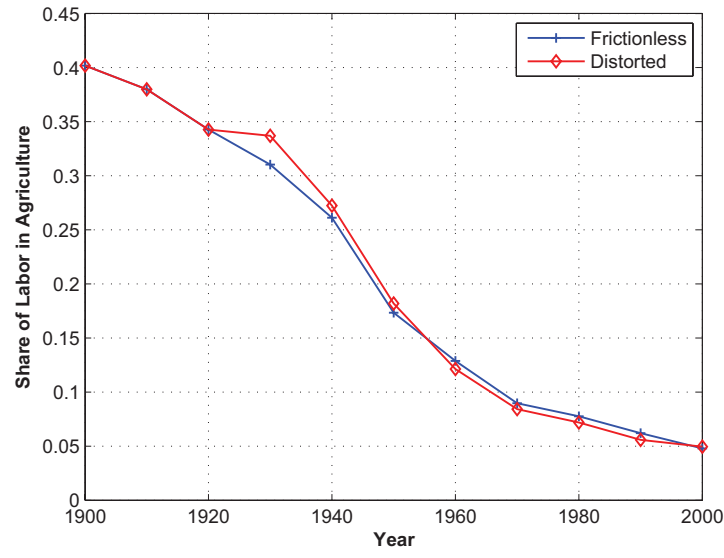

(a) Share of Labor in Agriculture

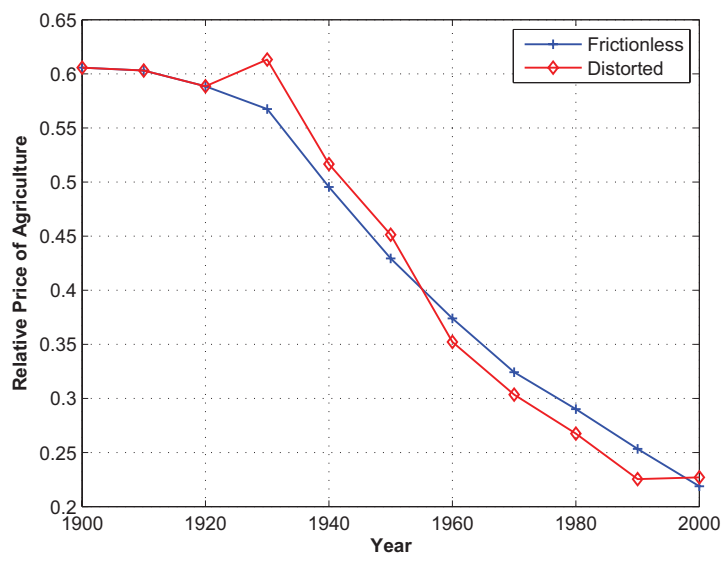

(c) Relative Price of Output

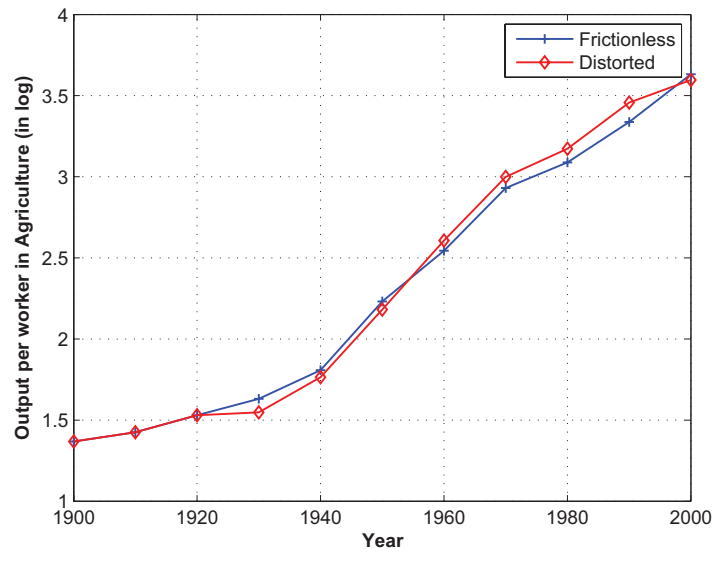

(b) Value Added per worker in Agriculture

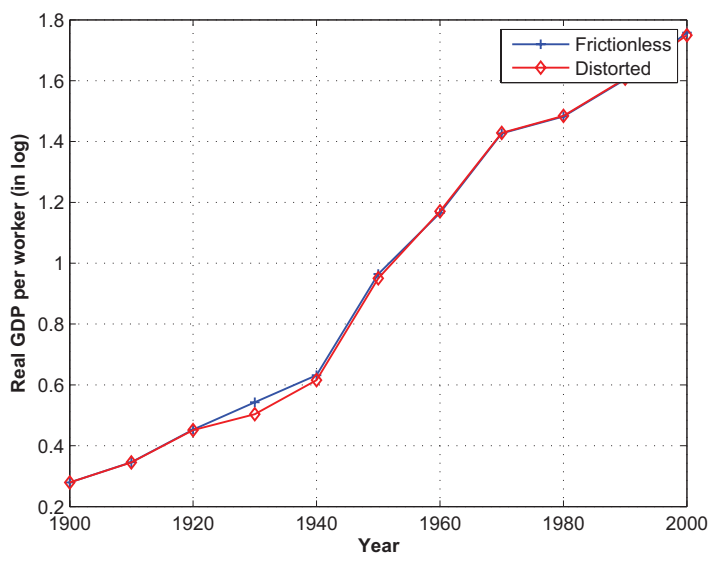

(d) Aggregate GDP per worker 
Figure 7: Lorenz Curve of Capital, Land, and Output in 2002
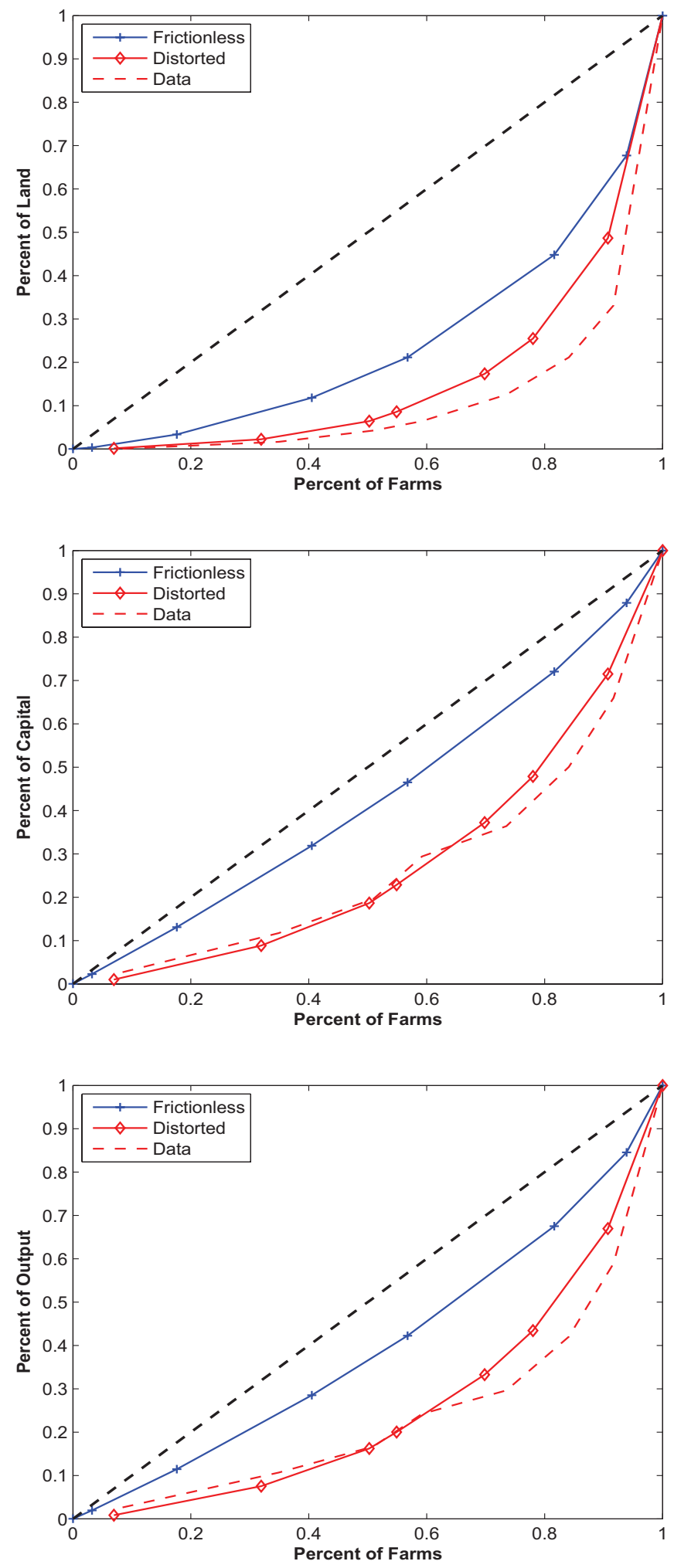
Figure 8: Gini Coefficient for Land, Capital and Output
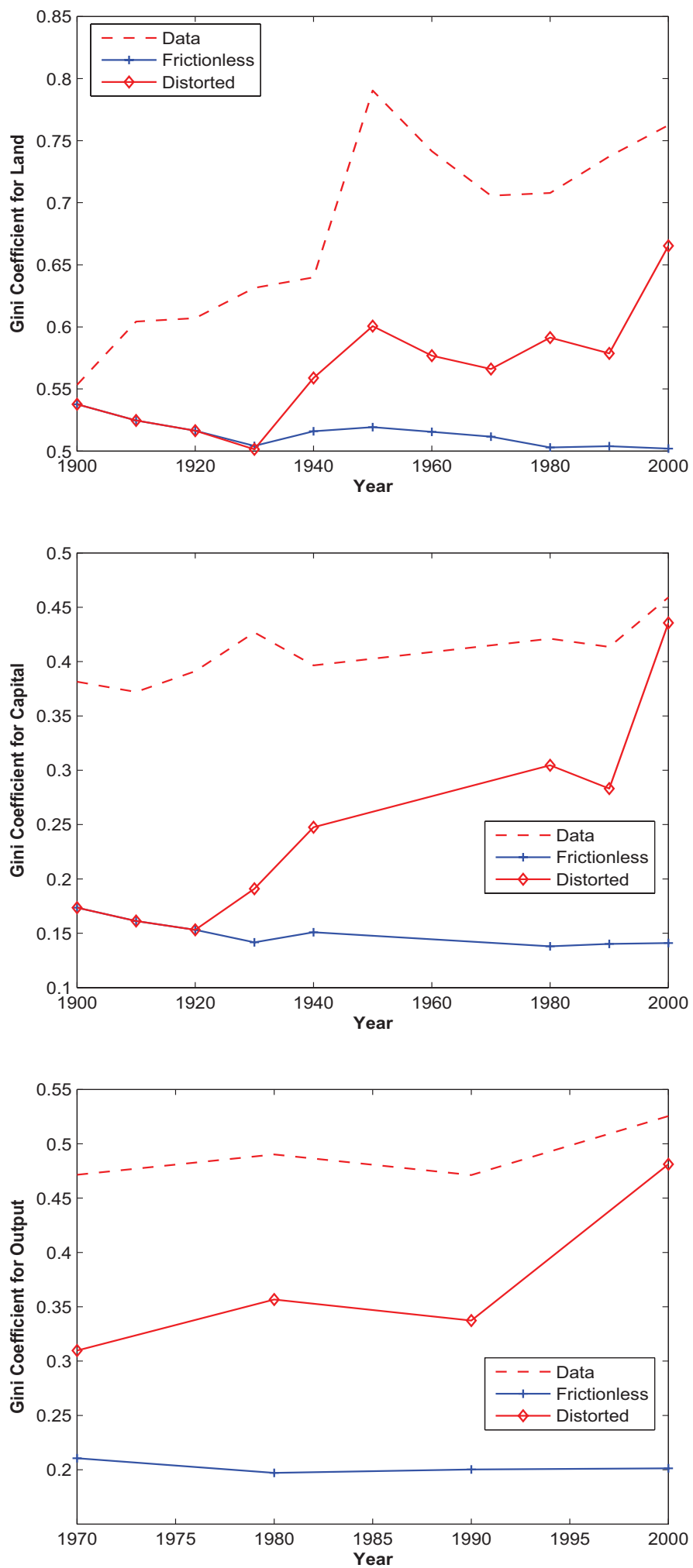
Figure 9: Implicit Farm Distortions $(1-\tau(s))$

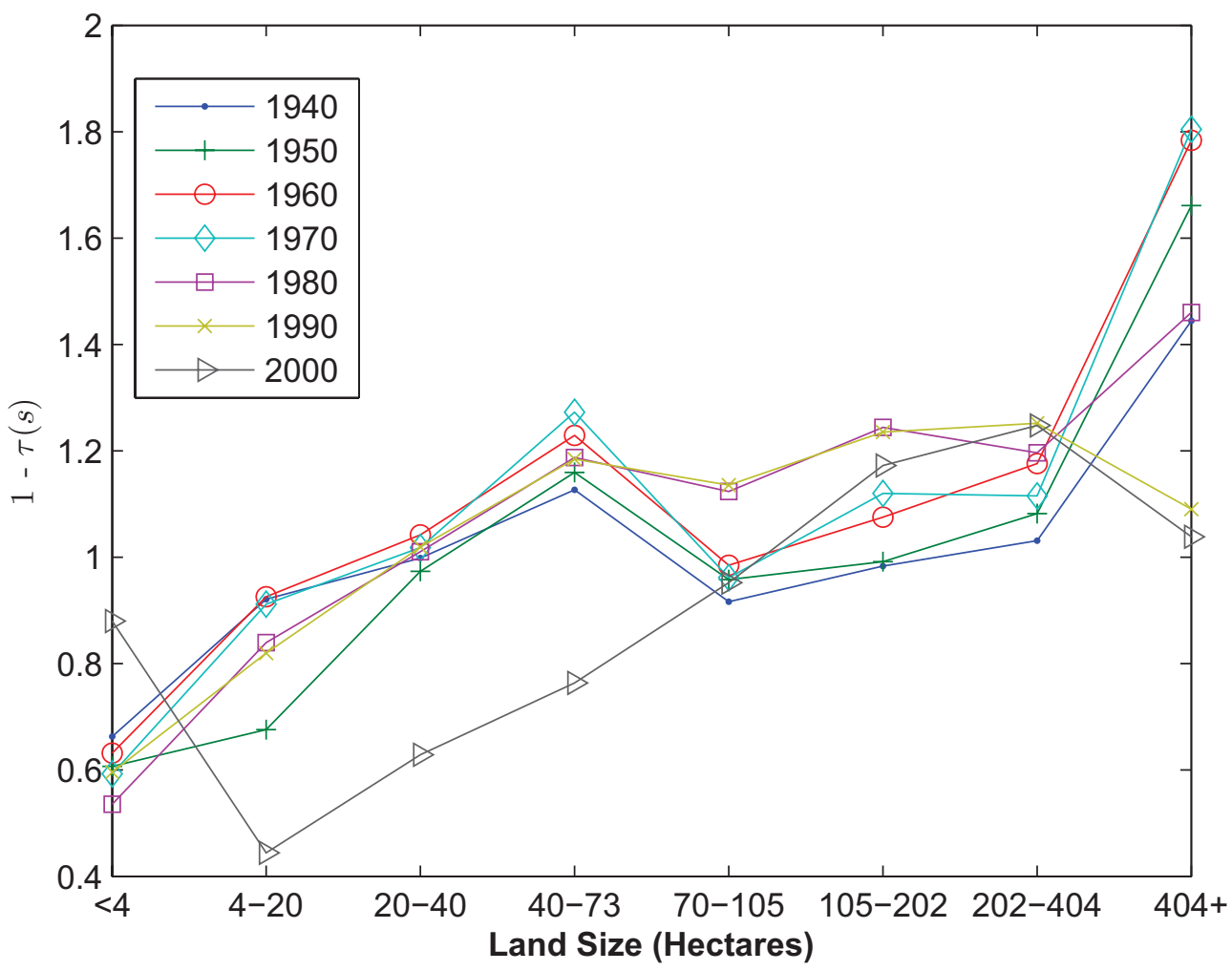

